\title{
Antioxidative effects of stabilized and unstabilized defatted rice bran methanolic extracts on the stability of rice bran oil under accelerated conditions
}

\author{
By Abdalbasit Adam Mariod, ${ }^{\text {ac }}$ Hadiza Altine Adamu, ${ }^{\text {ab }}$ Maznah Ismail ${ }^{\mathrm{b}^{*}}$ and Norsharina Ismail ${ }^{\text {ab }}$
}

\author{
${ }^{a}$ Laboratory of Molecular Biomedicine, Institute of Bioscience, University of Putra Malaysia, 43400 UPM \\ Serdang, Selangor. Malaysia. \\ ${ }^{\mathrm{b}}$ Department of Nutrition and Dietetic, Faculty of Medicine and Health Sciences, University of Putra \\ Malaysia, 43400 UPM Serdang, Selangor. Malaysia. \\ 'Department of Food Science \& Technology, Sudan University of Science \& Technology, P. O Box 71, \\ Khartoum North, Sudan. \\ ( ${ }^{\star}$ Corresponding author: maznah@ medic.upm.edu.my or myhome.e@gmail.com)
}

\section{RESUMEN}

Efecto antioxidante de extractos metanólicos de salvado de arroz desengrasado estabilizado y no-estabilizado en la estabilidad de aceite de salvado de arroz bajo condiciones aceleradas.

La presente investigación evalúa la actividad antioxidante mediante el radical sintético 1,1-difenil-2-picrilhidrazil y el ensayo $\beta$-caroteno-ácido linoleico de extractos metanólicos de salvado de arroz desengrasado procedente de salvado de arroz estabilizado y no-estabilizado. El efecto de los extractos $(0.1$ y $0.25 \% \mathrm{w} / \mathrm{w})$ sobre la estabilidad oxidativa del aceite refinado de salvado de arroz fue determinado y comparado con el del BHA (antioxidante sintético). El estudio fue llevado a cabo durante un periodo de $168 \mathrm{hr}$ a $70^{\circ} \mathrm{C}$ y la progresión de la oxidación fue medida mediante el valor de peróxidos, valor de $p$-anisidine y substancias reactivas del ácido tiobarbitúrico (TBARS). El porcentaje relativo del $\alpha$-tocoferol y $\gamma$-orizanol residual en el aceite de germen de arroz conteniendo extracto metanólico de germen de arroz desengrasado estabilizado y no estabilizado durante el almacenamiento a $70^{\circ} \mathrm{C}$ fueron estudiados.

PALABRAS CLAVE: Aceite de germen de arroz - Actividad antioxidante - Estabilidad - Germen de arroz desengrasado y estabilizado

\section{SUMMARY}

Antioxidative effects of stabilized and unstabilized defatted rice bran methanolic extracts on the stability of rice bran oil under accelerated conditions.

The present research assessed the antioxidant activity against the synthetic 1,1-diphenyl-2-picrylhydrazyl radical, and $\beta$-carotene-linoleic acid assay of the methanolic extracts of defatted rice bran from stabilized and unstabilized rice bran. The effects of the extracts $(0.1$ and $0.25 \% \mathrm{w} / \mathrm{w})$ on the oxidative stability of refined-bleached rice bran oil were determined and compared with those of BHA (synthetic antioxidant). The study was carried out over a $168 \mathrm{hr}$ period at $70^{\circ} \mathrm{C}$ and the progression of oxidation was measured by peroxide value, $p$-anisidine value, and thiobarbituric acid-reactive substances (TBARS). The relative $\%$ of residual $\alpha$-tocopherol and $\gamma$-oryzanol of the rice bran oil containing methanolic extracts of stabilized and unstabilized defatted rice bran during storage at $70^{\circ} \mathrm{C}$ were studied.

KEY-WORDS: Antioxidant activity - Rice bran oil - Stability - Stabilized defatted rice bran.

\section{INTRODUCTION}

Many studies have focused on rice bran as a source of natural antioxidants e.g. rice bran (Chotimarkorn et al., 2008) and defatted rice bran (Devi and Arumughan, 2007), which is the predominant byproduct of rice bran oil and a good source of insoluble dietary fiber, protein, phytic acid, inositol and vitamin B (Hargrove, 1994). The antioxidant potential of defatted rice bran was also determined (Shin et al., 1992; Devi et al., 2007), but it still remains a relatively unexplored source material, which demands further investigation especially with regards to its phytochemical composition related to possible health benefits as antioxidants. According to literature reports, several authors have demonstrated the antioxidative effects of rice bran extracts such as free radical scavenging, chelating ability and reducing power in vitro systems (lqbal et al., 2005; Nam et al., 2006). However, stabilized and unstabilized defatted rice bran extracts have not been investigated as a source of natural antioxidant substitutes for synthetic antioxidants in bulk oil during storage. Moreover, the changes in the antioxidative components of crude defatted rice bran extracts have not been explored during autoxidation. The objectives of this research were to investigate the phenolic compounds of stabilized and unstabilized defatted rice bran extracts and to evaluate their antioxidant activity $(A O A)$ using different in vitro methods. The different extracts were dissolved in a small amount of methanol and applied to rice bran oil at levels of 0.25 and $0.5 \%$ to examine their antioxidative activity; the development of the peroxide, anisidine, conjugated deine (CD), and TBRAS values during the oxidation of rice bran oil were also evaluated at $70^{\circ} \mathrm{C}$ for 168 hour.

\section{MATERIALS AND METHOD}

\subsection{Materials}

All solvents used were of analytical grade. Methanol, ethyl acetate, hexane, chloroform, butylated 
hydroxyanisole (BHA), $\beta$-carotene, linoleic acid and Folin-Ciocalteau reagent as well as polyoxyethylene sorbitan monopalmitate (Tween 40) were obtained from Merck (Merck, Darmstadt, Germany). (+)- $\alpha$-tocopherol (Sigma-Aldrich Co., St. Louis, MO, USA),

Rice bran samples were obtained from a local milling factory in Tanjung Karang, Selangor, Malaysia. Samples were collected directly from the milling system and immediately placed in square plastic (polypropylene) containers that were halffilled and transported to the Molecular Biomedicine Laboratory of the Institute of Bioscince, IBS, UPM Serdang in a cool box. To stabilize the rice bran samples, they were heated for $2 \mathrm{~min}$ at $2450 \mathrm{MHz}$, using a national microwave/convection oven (model NN-C2003S, Matsushita Electric Industrial Co., Japan). The heating was carried out one by one until all samples had been heated. The stabilized samples were left to cool at room temperature before sealing the lids with cellophane tape. Samples of stabilized rice bran (SRB) and unstabilized rice bran (USRB) were stored at $4^{\circ} \mathrm{C}$ in a cold room until further analyses.

\section{Rice bran oil}

The refined edible rice bran oil which was produced by Green Love Distribution Sdn Bhd, Kuala Lumpur, Malaysia was obtained from the local store Serdang, Malaysia; the oil was free of any synthetic antioxidant.

\subsection{Methods}

\section{Extraction of phenolic compounds}

Twenty grams of the dried defatted (stabilized SRB and unstabilized USRB) rice bran were extracted successively with $80 \%$ methanol (3x200ml) by sonication (Hwasin Technology, Seoul, Korea) to obtain methanolic extract at room temperature for 1 hour. The extracts were filtrated through Whatman no. 1 filter paper and the solvent was removed. The residual of defatted rice bran was further extracted twice with $80 \%$ methanol and the extracts were combined. Then the solvents were removed using a rotary evaporator (Buchi, Flawil, Switzerland) at $40^{\circ} \mathrm{C}$ and subjected to a nitrogen gas flow until dry (Devi and Arumughan, 2007). The yield of each extract was measured before storing at $-80^{\circ} \mathrm{C}$ for further analysis. The total phenolic (TPC) in the methanolic extracts of defatted rice bran was determined with the FolinCiocalteu reagent following the method of Kaur et al. (2008) using gallic acid as standard. The TPC of the sample was expressed as gallic acid in terms of $\mathrm{mg}$ gallic acid equivalents (GAE)/100 g dried samples.

\section{The antioxidant activity}

The antioxidant activity of phenolic extracts from defatted (stabilized SRB and unstabilized USRB) rice bran was measured using the stable radical 1,1-diphenyl-2-picrylhydrazyl (DPPH) according to Gordon et al.(2001) and using $\beta$-carotene-linoleic acid assay according to the method of Amarowicz et al. (2003). All determinations were performed in triplicate. The collected different methanolic rice bran extracts were applied to $100 \mathrm{~g}$ commercial edible rice bran oil obtained from a local market (free of any antioxidant) at levels of $0.1 \%$ and $0.25 \%$ to examine their antioxidative activity. BHA at a level of 0.02 $\%$ was used as a standard. A control sample was prepared using the same amount of methanol used to dissolve the antioxidant and the extracts (Moure et al., 2001). The commercial rice bran oil with added antioxidants was heated at $70^{\circ} \mathrm{C}$ for 168 hours. Samples $(5 \mathrm{~g})$ were removed periodically every 24 , 48, 72, 96, 120, 144 and 168 hours for analysis. Peroxide value (PV) and $p$-anisidine value (AV), and thiobarbituric acid-reactive substances (TBARS) were determined by the (AOCS, 1993) methods.

TBARS test. Each sample (200 mg) was weighed into a $25-\mathrm{mL}$ volumetric flask. It was then made up to the mark with 1-butanol (ACS grade) and mixed thoroughly. A $5-\mathrm{mL}$ portion of this solution was transferred into a dry test tube, and a $5-\mathrm{mL}$ quantity of fresh TBA reagent (200 mg TBA in $100 \mathrm{~mL} 1$-butanol) was added to it. The tube was placed in a $95^{\circ} \mathrm{C}$ water bath for $120 \mathrm{~min}$. The tube was cooled, and the absorbance of the solution was read at $532 \mathrm{~nm}$. The TBARS value was calculated as follows:

TBARS value $=\left(A^{*} 0.415\right) / m$ (Chirinos et al., 2009).

where $A=$ absorbance at $532 \mathrm{~nm}$ and $m=$ mass of the sample

\section{Identification of phenolic compounds}

Phenolic compounds were identified and quantified by comparing their retention time and UV-Vis spectral data to known previously injected standards (Chirinos et al., 2009). The changes in gamma-oryzanol and $\alpha$-tocopherol content in rice bran oil treated with rice bran methanolic extract during storage were measured according to the method of Rogers et al. (1993) The content of gamma-oryzanol and $\alpha$-tocopherol were quantified using the HPLC system consisting of a Hewlett-Packard (Germany) Model G1311A HPLC connected to an ALS Auto-injector Series 1100 (Hewlett Packard, Germany) based on the peak area of the standard curve of standard gamma-oryzanol and $\alpha$-tocopherol.

\section{Statistical analyses}

Statistical analyses were conducted using SPSS (Statistical Program for Social Sciences, SPSS Corporation, Chicago, IL) version 12.0 for Windows. The analysis of variance (ANOVA) and Pearson's correlation coefficients were performed to compare the data. All determinations were done at least in triplicate and all were averaged. The confidence limits used in this study were based on $95 \%(P<0.05)$. 


\section{RESULTS AND DISCUSSION}

\subsection{Phenolic compound analysis}

Previous research has been interested in the identification of phenolic compounds from various natural sources (Moure, 2000; Mariod et al., 2009a; Mariod et al., 2009b). Rice bran was one of the most potential sources of plant phytochemicals. However, the content and stability of phenolic compounds in stabilized and unstabilized defatted rice bran extracts have not previously been investigated. The content of the total phenolic compounds of methanolic extracts from stabilized defatted rice bran (SRB) and unstabilized defatted rice bran (USRB) expressed as gallic acid equivalents are shown in Table 1. The results in this table reveal that the SRB exhibited a higher phenolic content of $519.6 \mathrm{mg} / 100 \mathrm{~g}$ GAE followed by the USRB extract $(480.1 \mathrm{mg} / 100 \mathrm{~g})$. These results were higher than the previous results of Devi and Arumughan (2007), who reported 5.3\% of total phenolics in defatted rice bran, and Chatha et al. (2006) who reported that the TPC of different rice bran extracts ranged from $250-397 \mathrm{mg} / 100 \mathrm{~g}$ with $80 \%$ methanol as the most efficient solvent system in extracting the phenolic antioxidants from rice bran as compared with other solvents. Gerard and Roberts (2004) reported that the total phenolic and flavonoid content of apple juice increased with increasing microwave heating. In contrast, AbdulHamid et al. (2007) reported that total phenolics present in stabilized rice bran showed decreasing concentrations in different milling fractions.

\subsection{Antioxidant activity assessment}

The antioxidant activity of SRB and USRB extracts was evaluated through the DPPH method and the results are presented in terms of $\mathrm{IC}_{50}$ (Table 1 ). The $I C_{50}$ values of the scavenging activities on
DPPH radical were found to be $0.69 \mathrm{mg} / \mathrm{ml}, 0.79 \mathrm{mg} /$ $\mathrm{ml}$, and $0.17 \mathrm{mg} / \mathrm{ml}$ for SRB, USRB and ascorbic acid (standard), respectively. The DPPH radicalscavenging activity was found to be in the order of ascorbic acid $>$ SRB $>$ USRB. The stabilized defatted rice bran extract showed the most potent activity. This radical-scavenging activity of extracts could be related to the nature of phenolic compounds or might be related to compounds other than phenolics.

Table 1 shows the individual phenolic acids found in the methanolic extract of SRB and USRB respectively, monitored at $280 \mathrm{~nm}$. Gallic, chlorogenic, syringic, vanillin, and ferulic acids were the predominant phenolics showing the levels of $0.003,0.008,0.004,0.006$ and $0.005 \mathrm{mg} / 100 \mathrm{~g} \mathrm{DW}$, in USRB, respectively. While in SRB fewer levels of $0.002,0.003$ and $0.003 \mathrm{mg} / 100 \mathrm{~g}$ in SRB for syringic, vanillin, and ferulic acids were found.

\subsection{Lipid oxidation compound assessment}

Increasing primary and secondary lipid peroxidation products of rice bran oil treated with phenolic extract from SRB and USRB during 168 $\mathrm{hr}$ storage were measured by peroxide, $p$-anisidine and thiobarbituric acid reactive substance (TBARS) values. The changes in peroxide value (PV) of the treated oils as a function of time are shown in Table 2. Rice bran oil treated with SRB, and USRB exhibited lower PV $(<50 \%)$ for up to $168 \mathrm{hr}$ as compared with the control sample. Also, samples treated with synthetic antioxidants (BHA) showed lower peroxide values than the control tested in this work. Among all samples tested, SRB served best in lowering peroxide formation and it was superior to USRB samples and gave peroxide values of $3.2,6.9,10.4$ and 22.5 (meq/kg oil) on hrs 0, 24, 96, and 168, respectively; corresponding values of the control sample were 3.5 ,

Table 1

Total phenolic compounds (TPC) ${ }^{\star},(\mathrm{DPPH})^{\star}$ and individual phenolic compound content $\mathrm{mg} / 100 \mathrm{~g}$ in defatted rice methanolic extracts

\begin{tabular}{lcc}
\hline & SRB & USRB \\
\hline TPC GAE $(\mathrm{mg} / 100 \mathrm{~g})$ & $519.6 \pm 0.51$ & $480.1 \pm 0.41$ \\
DPPH IC $_{50}(\mathrm{mg} / \mathrm{ml})$ & $0.69 \pm 0.31$ & $0.79 \pm 0.25$ \\
Phenolic compounds & $\mathrm{Nd}$ & \\
Gallic acid $(\mathrm{mg} / 100 \mathrm{~g})$ & $\mathrm{nd}$ & $0.003 \pm 0.002$ \\
Chlorogenic acid $(\mathrm{mg} / 100 \mathrm{~g})$ & $0.002 \pm 0.002$ & $0.008 \pm 0.001$ \\
Syringic acid $(\mathrm{mg} / 100 \mathrm{~g})$ & $0.003 \pm 0.001$ & $0.004 \pm 0.003$ \\
Vanillin $(\mathrm{mg} / 100 \mathrm{~g})$ & $0.003 \pm 0.001$ & $0.006 \pm 0.002$ \\
Ferulic acid $(\mathrm{mg} / 100 \mathrm{~g})$ & & $0.005 \pm 0.001$ \\
\hline
\end{tabular}

*Values are means \pm SD $(n=3)$, and they are given as $\mathrm{mg} / 100 \mathrm{~g}$ dry weight of investigated defatted rice bran extracts. nd: not detected, BHA: butylated hydroxyanisol, SRB: stabilized defatted rice bran, USRB: unstabilized defatted rice bran. Phenolic compounds were detected in SRB and USR by HPLC-DAD. DPPH free radical (expressed as mg extract allowing reduction of $50 \%$ DPPH). 
Table 2

Peroxide, anisidine values and thiobarbituric acid reactive substances of defatted stabilized and unstabilized rice bran methanolic extract at 100, 250mg/100 g and BHA at $200 \mathrm{ppm}$ in rice bran oil at hour 0 and 168 of storage at $70^{\circ} \mathrm{c}^{\star}$

\begin{tabular}{|c|c|c|c|c|c|c|}
\hline \multicolumn{7}{|c|}{ Peroxide value (PV) } \\
\hline Time[hr] & Control & $B H A$ & SRB 100 & SRB 250 & USRB 100 & USRB 250 \\
\hline 0 & $3.5 \pm 0.1$ & $3.2 \pm 0.1$ & $3.2 \pm 0.1$ & $3.2 \pm 0.1$ & $3.3 \pm 0.1$ & $3.3 \pm 0.1$ \\
\hline 6 & $7.9 \pm 0.3$ & $3.4 \pm 0.1$ & $4.5 \pm 0.2$ & $3.8 \pm 0.1$ & $5.4 \pm 0.2$ & $4.8 \pm 0.2$ \\
\hline 12 & $9.4 \pm 0.4$ & $3.7 \pm 0.1$ & $5.9 \pm 0.2$ & $4.7 \pm 0.2$ & $7.4 \pm 0.3$ & $6.7 \pm 0.3$ \\
\hline 24 & $12.7 \pm 0.5$ & $4.5 \pm 0.1$ & $6.9 \pm 0.2$ & $5.5 \pm 0.2$ & $8.8 \pm 0.3$ & $7.8 \pm 0.3$ \\
\hline 48 & $16.4 \pm 0.6$ & $4.9 \pm 0.2$ & $7.5 \pm 0.3$ & $5.9 \pm 0.2$ & $10.9 \pm 0.4$ & $8.9 \pm 0.3$ \\
\hline 72 & $20.0 \pm 1.1$ & $5.2 \pm 0.2$ & $8.4 \pm 0.3$ & $7.2 \pm 0.3$ & $12.4 \pm 0.5$ & $10.0 \pm 0.4$ \\
\hline 96 & $23.5 \pm 2.3$ & $7.0 \pm 0.2$ & $10.4 \pm 0.4$ & $8.8 \pm 0.3$ & $15.2 \pm 0.5$ & $13.8 \pm 0.5$ \\
\hline 120 & $27.2 \pm 2.1$ & $8.5 \pm 0.3$ & $14.8 \pm 0.5$ & $12.5 \pm 0.4$ & $18.4 \pm 1.3$ & $16.9 \pm 0.6$ \\
\hline 144 & $31.1 \pm 3.0$ & $11.3 \pm 0.5$ & $17.8 \pm 0.6$ & $15.3 \pm 0.6$ & $22.2 \pm 2.1$ & $19.8 \pm 0.7$ \\
\hline 168 & $34.4 \pm 3.3$ & $14.6 \pm 0.5$ & $22.5 \pm 2.4$ & $18.6 \pm 0.7$ & $26.6 \pm 2.3$ & $25.1 \pm 2.6$ \\
\hline \multicolumn{7}{|c|}{ Anisidine value (AV) } \\
\hline 0 & $0.5 \pm 0.1$ & $0.4 \pm 0.1$ & $0.4 \pm 0.1$ & $0.4 \pm 0.1$ & $0.4 \pm 0.1$ & $0.4 \pm 0.1$ \\
\hline 6 & $0.8 \pm 0.2$ & $0.5 \pm 0.1$ & $0.6 \pm 0.1$ & $0.6 \pm 0.1$ & $0.9 \pm 0.2$ & $0.7 \pm 0.2$ \\
\hline 12 & $1.8 \pm 0.4$ & $0.6 \pm 0.1$ & $1.2 \pm 0.3$ & $0.8 \pm 0.2$ & $1.8 \pm 0.4$ & $1.5 \pm 0.4$ \\
\hline 24 & $2.9 \pm 0.5$ & $0.8 \pm 0.2$ & $1.4 \pm 0.3$ & $1.1 \pm 0.3$ & $2.2 \pm 0.4$ & $1.8 \pm 0.4$ \\
\hline 48 & $3.7 \pm 0.6$ & $1.2 \pm 0.3$ & $1.6 \pm 0.3$ & $1.4 \pm 0.3$ & $2.6 \pm 0.4$ & $2.2 \pm 0.4$ \\
\hline 72 & $4.6 \pm 0.8$ & $1.5 \pm 0.3$ & $2.1 \pm 0.4$ & $1.8 \pm 0.3$ & $2.9 \pm 0.5$ & $2.6 \pm 0.4$ \\
\hline 96 & $4.9 \pm 0.8$ & $1.8 \pm 0.3$ & $2.6 \pm 0.5$ & $2.2 \pm 0.4$ & $3.2 \pm 0.5$ & $2.8 \pm 0.5$ \\
\hline 120 & $5.3 \pm 1.1$ & $2.2 \pm 0.4$ & $2.9 \pm 0.5$ & $2.6 \pm 0.4$ & $3.6 \pm 0.6$ & $3.3 \pm 0.5$ \\
\hline 144 & $5.9 \pm 1.2$ & $2.8 \pm 0.5$ & $3.5 \pm 0.6$ & $3.3 \pm 0.6$ & $4.6 \pm 0.8$ & $3.8 \pm 0.6$ \\
\hline 168 & $6.5 \pm 1.3$ & $3.0 \pm 0.5$ & $3.8 \pm 0.6$ & $3.5 \pm 0.6$ & $5.1 \pm 1.0$ & $4.3 \pm 0.7$ \\
\hline \multicolumn{7}{|c|}{ Thiobarbituric acid reactive substances (TBARS) } \\
\hline 0 & $0.9 \pm 0.4$ & $0.2 \pm 0.1$ & $0.5 \pm 0.1$ & $0.4 \pm 0.1$ & $0.6 \pm 0.2$ & $0.5 \pm 0.1$ \\
\hline 6 & $2.9 \pm 0.7$ & $0.5 \pm 0.1$ & $1.2 \pm 0.4$ & $0.8 \pm 0.3$ & $1.8 \pm 0.4$ & $1.6 \pm 0.5$ \\
\hline 12 & $5.1 \pm 0.9$ & $0.8 \pm 0.3$ & $1.5 \pm 0.4$ & $1.1 \pm 0.4$ & $1.9 \pm 0.5$ & $1.7 \pm 0.5$ \\
\hline 24 & $6.8 \pm 0.9$ & $1.1 \pm 0.4$ & $1.6 \pm 0.4$ & $1.2 \pm 0.4$ & $2.2 \pm 0.6$ & $2.0 \pm 0.6$ \\
\hline 48 & $8.7 \pm 1.1$ & $1.3 \pm 0.4$ & $2.1 \pm 0.6$ & $1.6 \pm 0.4$ & $2.6 \pm 0.7$ & $2.3 \pm 0.6$ \\
\hline 72 & $11.2 \pm 0.3$ & $2.2 \pm 0.6$ & $3.1 \pm 0.3$ & $2.2 \pm 0.6$ & $3.8 \pm 0.8$ & $3.4 \pm 0.3$ \\
\hline 96 & $13.8 \pm 0.2$ & $3.4 \pm 0.8$ & $5.1 \pm 0.9$ & $4.2 \pm 0.3$ & $6.2 \pm 0.4$ & $5.2 \pm 0.3$ \\
\hline 120 & $15.3 \pm 0.4$ & $4.7 \pm 0.2$ & $6.6 \pm 0.2$ & $5.6 \pm 0.2$ & $7.6 \pm 0.2$ & $6.6 \pm 0.2$ \\
\hline 144 & $16.4 \pm 0.5$ & $5.2 \pm 0.3$ & $7.0 \pm 0.3$ & $6.7 \pm 0.3$ & $8.3 \pm 0.3$ & $7.8 \pm 0.2$ \\
\hline 168 & $20.4 \pm 0.4$ & $6.7 \pm 0.3$ & $7.7 \pm 0.4$ & $8.5 \pm 0.4$ & $9.6 \pm 0.3$ & $8.4 \pm 0.4$ \\
\hline
\end{tabular}

${ }^{\star}$ Results are mean values of three determinations \pm SD. Means in a row sharing the same superscript are not significantly $(P>0.05)$ different from one another. PV: (meqO2/kg oil), AV: (), TBARS: (as $\mu \mathrm{mol}$ malonaldehyde equivalents/g sample)

12.7, 23.5, and 34.4 (meq/kg oil). These data also indicate that the antioxidant activity of most of the natural antioxidants added as well as BHA decreased with the length of storage time. The antioxidant activity of SRB and USRB are concentration dependent. The main purpose of using antioxidants in lipids is to delay a significant accumulation of free radicals and thus to improve oxidative stability. Natural antioxidants extracted from defatted rice bran possessed good antioxidant activity and extended the storage time and decreased the formation of peroxides in rice bran oil less effectively than BHA.

The formation of $p$-anisidine values during the storage of rice bran oil containing $0.1 \%$, and $0.25 \%$ $(\mathrm{w} / \mathrm{w})$ of stabilized and unstabilized defatted rice bran extracts are shown in Table 2. Before storing 
Table 3

Decrease in $\alpha$-tocopherol, and $\gamma$-oryzanol contents of rice bran oil in various concentrations of antioxidants obtained from stabilized and unstabilized defatted rice bran during storage at $70^{\circ} \mathrm{c}$ for 168 hours *

\begin{tabular}{|c|c|c|c|c|}
\hline Antioxidant & $\begin{array}{l}\text { Concentration } \\
\text { (mg/100 g oil) }\end{array}$ & Storage time (hrs) & $\begin{array}{l}\alpha \text {-Tocopherol } \\
\text { (mg/100 g oil) }\end{array}$ & $\begin{array}{c}\gamma \text {-Oryzanol } \\
\text { ( } \mu \mathrm{g} / 100 \mathrm{~g} \text { oil) }\end{array}$ \\
\hline \multirow[t]{8}{*}{ Control } & & 0 & $13.2 \pm 0.8$ & $2.0 \pm 0.1$ \\
\hline & & 24 & $12.1 \pm 0.3$ & $1.3 \pm 0.3$ \\
\hline & & 48 & $11.7 \pm 0.2$ & $1.6 \pm 0.3$ \\
\hline & & 72 & $11.6 \pm 0.3$ & $1.5 \pm 0.2$ \\
\hline & & 96 & $11.6 \pm 0.5$ & $1.6 \pm 0.2$ \\
\hline & & 120 & $11.4 \pm 0.2$ & $1.5 \pm 0.3$ \\
\hline & & 144 & $10.9 \pm 0.3$ & $1.4 \pm 0.3$ \\
\hline & & 168 & $10.5 \pm 0.3$ & $1.2 \pm 0.1$ \\
\hline \multirow[t]{8}{*}{ USRB } & 100 & 0 & $16.8 \pm 0.2$ & $2.6 \pm 0.4$ \\
\hline & & 24 & $16.6 \pm 0.3$ & $2.5 \pm 0.3$ \\
\hline & & 48 & $16.4 \pm 1.1$ & $2.3 \pm 0.2$ \\
\hline & & 72 & $15.8 \pm 0.4$ & $2.3 \pm 0.1$ \\
\hline & & 96 & $15.2 \pm 0.2$ & $2.2 \pm 0.1$ \\
\hline & & 120 & $14.6 \pm 0.3$ & $2.2 \pm 0.1$ \\
\hline & & 144 & $14.2 \pm 0.1$ & $2.0 \pm 0.1$ \\
\hline & & 168 & $13.8 \pm 0.5$ & $1.8 \pm 0.2$ \\
\hline \multirow[t]{8}{*}{ USRB } & 250 & 0 & $17.9 \pm 0.2$ & $2.7 \pm 0.3$ \\
\hline & & 24 & $16.7 \pm 0.1$ & $2.4 \pm 0.3$ \\
\hline & & 48 & $16.4 \pm 0.1$ & $2.3 \pm 0.2$ \\
\hline & & 72 & $15.8 \pm 0.2$ & $2.3 \pm 0.2$ \\
\hline & & 96 & $15.4 \pm 0.1$ & $2.3 \pm 0.2$ \\
\hline & & 120 & $15.1 \pm 0.2$ & $2.3 \pm 0.3$ \\
\hline & & 144 & $14.6 \pm 0.1$ & $2.3 \pm 0.2$ \\
\hline & & 168 & $13.5 \pm 0.2$ & $2.3 \pm 0.2$ \\
\hline \multirow[t]{8}{*}{ SRB } & 100 & 0 & $15.6 \pm 0.2$ & $2.7 \pm 0.3$ \\
\hline & & 24 & $15.4 \pm 0.2$ & $2.2 \pm 0.1$ \\
\hline & & 48 & $15.2 \pm 0.1$ & $2.1 \pm 0.1$ \\
\hline & & 72 & $14.5 \pm 0.2$ & $2.1 \pm 0.1$ \\
\hline & & 96 & $13.9 \pm 0.1$ & $2.1 \pm 0.1$ \\
\hline & & 120 & $13.6 \pm 0.3$ & $2.0 \pm 0.1$ \\
\hline & & 144 & $13.4 \pm 0.2$ & $2.0 \pm 0.1$ \\
\hline & & 168 & $12.8 \pm 0.3$ & $2.0 \pm 0.1$ \\
\hline \multirow[t]{8}{*}{ SRB } & 250 & 0 & $16.9 \pm 0.3$ & $2.7 \pm 0.3$ \\
\hline & & 24 & $16.5 \pm 0.2$ & $2.4 \pm 0.2$ \\
\hline & & 48 & $16.2 \pm 0.2$ & $2.2 \pm 0.2$ \\
\hline & & 72 & $15.9 \pm 0.3$ & $2.1 \pm 0.1$ \\
\hline & & 96 & $15.8 \pm 0.1$ & $1.8 \pm 0.1$ \\
\hline & & 120 & $15.7 \pm 0.2$ & $1.6 \pm 0.1$ \\
\hline & & 144 & $15.5 \pm 0.1$ & $1.3 \pm 0.1$ \\
\hline & & 168 & $14.8 \pm 0.2$ & $1.1 \pm 0.1$ \\
\hline \multirow[t]{8}{*}{$\mathrm{BHA}$} & 20 & 0 & $13.2 \pm 0.2$ & $2.0 \pm 0.2$ \\
\hline & & 24 & $13.1 \pm 0.2$ & $1.8 \pm 0.1$ \\
\hline & & 48 & $12.9 \pm 0.2$ & $1.7 \pm 0.1$ \\
\hline & & 72 & $12.8 \pm 0.2$ & $1.6 \pm 0.1$ \\
\hline & & 96 & $12.7 \pm 0.2$ & $1.6 \pm 0.1$ \\
\hline & & 120 & $12.7 \pm 0.2$ & $1.5 \pm 0.1$ \\
\hline & & 144 & $12.5 \pm 0.2$ & $1.5 \pm 0.1$ \\
\hline & & 168 & $12.3 \pm 0.2$ & $1.4 \pm 0.1$ \\
\hline
\end{tabular}




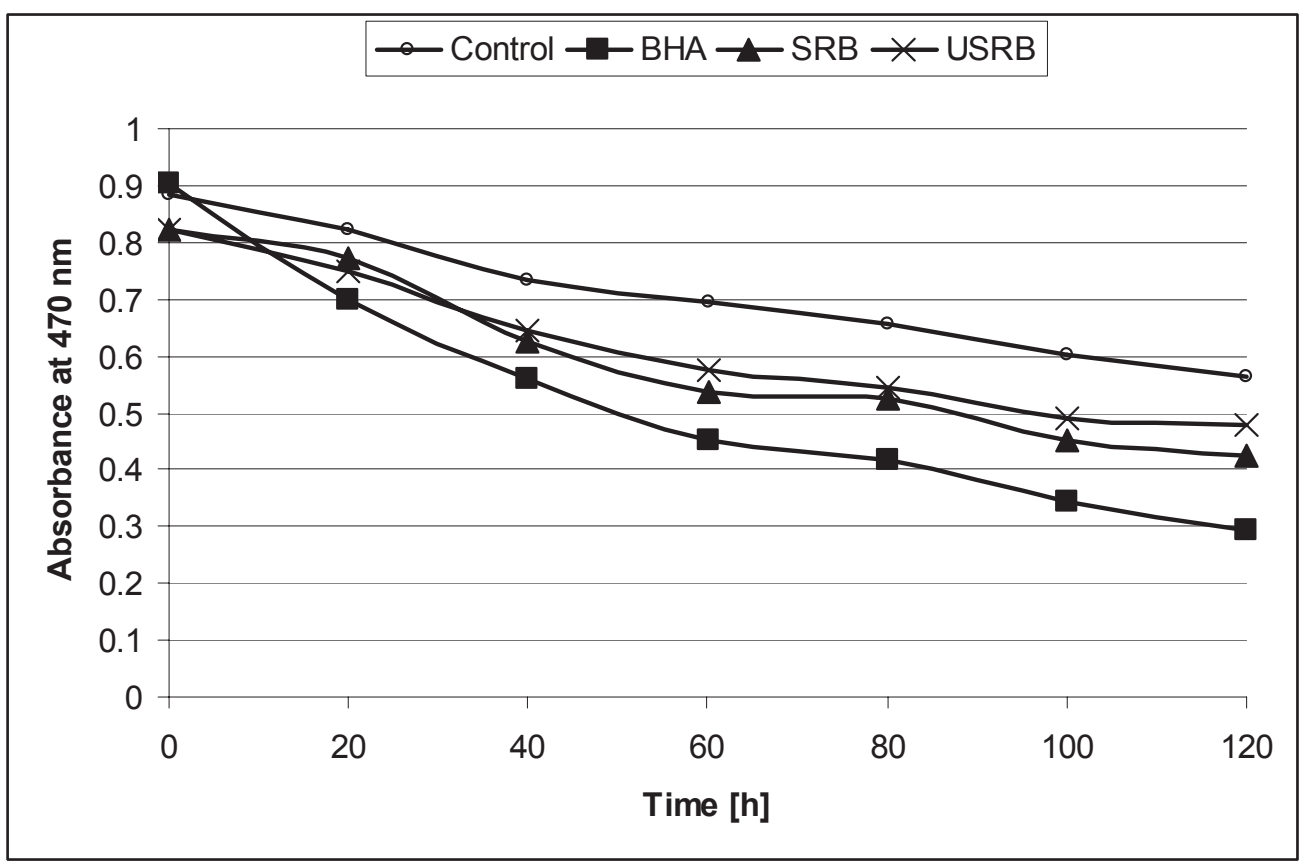

Figure 1.

Effect of stabilized and unstabilized defatted rice bran methanolic extracts (SRB, USRB and BHA) on oxidation of $\beta$-carotene/linoleic acid at $50^{\circ} \mathrm{C}$.

at $70 \mathrm{C}$, the initial $p$-anisidine value of rice bran oil was 0.5 . The $P$-anisidine values of rice bran oil without SRB, and USRB extracts were significantly higher $(p>0.05)$ than those of rice bran oil containing such extracts and BHA during storage. The $P$-anisidine value of rice bran oil without SRB and USRB extracts was rapidly increased $(p$ $>0.05$ ) to 4.9 after $96 \mathrm{hr}$ storage and it was also significantly different to the rice bran oil with SRB and USRB extracts after $48 \mathrm{hr}$ storage $(p>0.05)$. From the results presented in Table 2 , it can be concluded that the anisidine value of rice bran oil without defatted rice bran extracts after $24 \mathrm{hr}$ storage was significantly different $(p>0.05)$ to rice bran oil containing $0.1 \%(\mathrm{w} / \mathrm{w})$ of USRB and SRB extracts and $0.02 \%$ of $\mathrm{BHA}$ after 72,120 and 168 hr storage at $70 \mathrm{C}$, respectively.

The effects of the different extracts and synthetic antioxidants on the TBARS values of rice bran oil after accelerated oxidation at $70^{\circ} \mathrm{C}$ are shown in Table 2. TBARS formation of the control increased with an increase in storage time. However, the values for the samples treated with the defatted rice bran extracts and BHA were significantly $(P<0.05)$ lower than those of the control. Among the phenolic extracts used, SRB and USRB extracts at $250 \mathrm{mg}$ showed better antioxidant activity than at $100 \mathrm{mg}$ methanolic extract. The different extracts lowered the content of TBARS significantly $(P<0.05)$ after $168 \mathrm{hr}$ of storage. TBARS measure the formation of secondary oxidation products, which may contribute to the off-flavor of oxidized oil (Wanasundara and Shahidi, 1994). These results indicate that the SRB and USRB extracts exhibited antioxidant activity not only in $\beta$-carotene linoleic acid (Fig. 1) but also during rice bran oil peroxidation (Table 2).

\subsection{Endogenous antioxidant content}

Tocopherols and oryzanols are the main antioxidants present in rice bran. The antioxidant activity of oryzanols is almost 10 times higher than that of tocopherols. The changes of gamma-oryzanol and $\alpha$-tocopherol content in rice bran oil treated with rice bran methanolic extract during storage were measured according to method of Rogers et al., (1993), and the results are shown in Table 3. After 168 hrs of storage, the residual of $\alpha$-tocopherol content was reduced by 17.9 and $20.1 \%$ of initial rice bran oil containing 100 and $250 \mathrm{mg}$ USRB, respectively, 17.9 and $12.9 \%$ initial rice bran oil containing 100 and 250 mg SRB extracts, respectively.

Gamma-oryzanol contents in rice bran oil were decreased during the storage of defatted rice bran oil. The initial $\gamma$-oryzanol contents of rice bran oil containing 100 and $250 \mathrm{mg}$ USRB extracts were 2.6 , and $2.7 \mu \mathrm{g} / 100 \mathrm{~g}$ oil, respectively. After $168 \mathrm{hrs}$ of storage, the $\gamma$-oryzanol contents of rice bran oil added with 100 and $250 \mathrm{mg}$ USRB extracts were 1.8 and $2.3 \mu \mathrm{g} / 100 \mathrm{~g}$ oil, respectively. The initial $\gamma$-oryzanol contents of rice bran oil containing 100 and $250 \mathrm{mg} \mathrm{SRB}$ extracts were 2.7, and 2.7 $\mu \mathrm{g} / 100 \mathrm{~g}$ oil, respectively. After $168 \mathrm{hrs}$ of storage, the $\gamma$-oryzanol contents of rice bran oil added with 100 and $250 \mathrm{mg}$ SRB of rice bran extracts was 2.0 and $1.1 \mu \mathrm{g} / 100 \mathrm{~g}$ oil, respectively. These results were in good agreement with Nystrom et al., (2007) who reported that, $\gamma$-oryzanol was more heat stable than $\alpha$-tocopherol at high temperatures. Several studies found that the $\gamma$-oryzanol obtained from rice bran extracts had a strong stabilizing effect during storage and frying (Kochhar, 2000; Chotimarkorn and Silalai, 2008). 


\section{CONCLUSIONS}

From the present work, it could be concluded that stabilization of rice bran has a significant effect on its methanolic extract antioxidant properties and that antioxidant potential differs among the stabilized and unstabilized samples up to a significant extent. Peroxide, TBARS and $p$-anisidine values were reliable methods that can be used to determine the lipid peroxidation in rice bran oil, containing various concentrations of stabilized and unstabilized defatted rice bran extracts. These extracts when added in rice bran oil can reduce the changes of $\alpha$ - tocopherol, and $\gamma$-oryzanol contents due to lipid peroxidation during oil storage. Therefore, these extracts can provide potential sources of natural antioxidants suggesting their use in the inhibition of lipid oxidation in nutraceuticals and functional foods.

\section{REFERENCES}

Abdul-hamid A, Sulaiman RR, Osman A, Saari N. 2007. Preliminary study of the chemical composition of rice milling fractions stabilized by microwave heating. $J$. Food Comp. Analy. 20, 627-637.

Amarowicz R, Karamac M, Shahidi F. 2003. Antioxidant activity of phenolic fractions of lentil (Lens culinaris). Journal of Food Lipids 10, 1-10.

AOCS.1993. Official Methods and Recommended Practices of the American Oil Chemists' Society, 4th edn., AOCS Press, Champaign, IL.

Böhm V, Kühnert S, Rohm H, Scholze G. 2006. Improving the nutritional quality of microwave-vacuum dried strawberries: A preliminary study. Food Sci. Technol. Inter. 12, 67-75.

Chatha SAS, Anwar F, Manzoor M, Bajwa J. 2006. Evaluation of the antioxidant activity of rice bran extracts using different antioxidant assays. Grasas y Aceites 57, (3) 328-335.

Chirinos R, Betalleluz, I, Humána A, Arbizub C, Pedreschi R, Campos C. 2009. HPLC-DAD characterization of phenolic compounds from Andean oca (Oxalis tuberose Mol.) tubers and their contribution to the antioxidant capacity. Food Chem. 113, 1243-1251.

Chotimarkorn C, Benjakul S, Silalai N. 2008. Antioxidative effects of rice bran extracts on refined tuna oil during storage. Food Res. Inter. 41, 616-622.

Devi RR, Arumughan C. 2007. Antiradical efficacy of phytochemical extracts from defatted rice bran. Food Chem. Toxicol. 45, 2014-2021.

Gerard KA, Roberts JS. 2004. Microwave heating of apple mash to improve juice yield and quality. LebensmittelWissenschaft und-Technologie 37, 551-557.
Gordon MH, Paiva-martins F, Almeida M. 2001. Antioxidant activity of hydroxytyrosol acetate compared with that of other olive oil polyphenols. J. Agric. Food Chem. 49 , 2480-2485

Hargrove JR. KL. 1994. Processing and utilization of rice bran in the United States. In: Marshall WE, Wadsworth Jl. (Eds.), Rice Science and Technology 381-404. Marcel Decker Inc., New York,

lqbal S, Bhanger M I, Anwar F. 2005. Antioxidant properties and components of some commercially available varieties of rice bran in Pakistan. Food Chem. 93, 265272.

Kaur R, Arora S, Singh B. 2008. Antioxidant activity of the phenol rich fractions of leaves of Chukrasia tabularis A. Juss. Biores. Technol. 99, 7692-7698.

Kochhar SP. 2000. Stable and healthful frying oil for 12th century. Inform 11, 642-647.

Mariod AA, Ibrahim R I, Ismail M, Ismail N. 2009a. Antioxidant activities of phenolic rich fractions (PRFs) obtained from black mahlab (Monechma ciliatum) and white mahlab (Prunus mahaleb) seedcakes. Food Chem. 118, 120-127

Mariod AA, Ibrahim RI, Ismail M, Ismail N. 2009b. Antioxidant activity and phenolic content of phenolic rich fractions obtained from black cumin (Nigella sativa) seedcakes. Food Chem. 116, 306-312.

Moure A, Cruz JM, Franco D, Dominguez JM, Sineiro J, Dominguez H. 2001. Natural antioxidants from residual sources. Food Chem. 72, 145-171.

Nam SH, Choi SP, Kang MY, Kho HJ, Kozukue N, Griedman M. 2006. Antioxidative activities of bran extracts from twenty one pigmented rice cultivars. Food Chem. 94, 613-620.

Nystrom L, Arcrenius T, Lampi AM, Moreau RA, Piironen V. 2007. Comparison of the antioxidant properties of steryl ferulates with tocopherol at high temperature. Food Chem. 101, 947-954.

Rogers EJ, Rice SM, Nicolosi RJ, Carpenter DR, McClelland CA, Romancyzk LJ. 1993. Identification and quantification of $\gamma$-oryzanol components and simultaneous assessment of tocols in rice bran oil. $J$. Am. Oil Chem. Soc.70, 301-307.

Shin ZI, Chang YS, Kang WS, Jung SU. 1992. Antioxidant extracted from the defatted rice bran. US Patent $5,175,012$.

Wanasundara UN, Shahidi F. 1994. Canola Extracts as an Alternative Natural Antioxidant for Canola Oil. J. Am. Oil Chem. Soc. 71, 817-822.

Wettasinghe M, Shahidi F, Amarowics R. 2002. Identification and quantification of low molecular weight phenolic antioxidants in seeds of evening primrose (Oenothera biennis L.). Journal of Agricultural and Food Chem. 50, 1267-1271. 